Piia Nuora is a postdoctoral researcher at the Department of Chemistry, University of Jyväskylä, Finland. Her research is mainly focused on Chemistry Education, Higher Education and out-of-school learning in STEM subjects.

Jouni Välisaari received his PhD in the year 1999, in Inorganic and Analytical Chemistry from University of Jyväskylä, Finland. He received MA (Educ.) in the year 2011 in Faculty of Education from University of Jyväskylä, Finland. Jouni Välisaari is currently working as a Senior Lecturer at the Department of Chemistry at the University of Jyväskylä, Finland. His teaching and research interests are focused on Chemistry Education.

Tiina Kiviniemi works as a University Teacher at the Department of Chemistry, University of Jyväskylä. She teaches and gives study counselling to Chemistry students at Bachelor level. Her research is focused mainly on understanding and developing teaching and learning processes in Bachelor level University Chemistry Education.

\title{
PIIA NUORA
}

University of Jyväskylä, Department of Chemistry, Finland

piia.nuora@jyu.fi

\section{JOUNI VÄLISAARI}

University of Jyväskylä, Department of Chemistry, Finland jouni.valisaari@jyu.fi

\section{TIINA KIVINIEMI}

University of Jyväskylä, Department of Chemistry, Finland tiina.t.kiviniemi@jyu.fi

\section{Adolescents' perceptions of scientific Inquiry in nature: a drawing analysis}

\begin{abstract}
This study was carried out to determine adolescents' perception of scientific inquiry (SI) in nature and the effect of a science camp on those perceptions. Eleven science campers (14 to 16 years old) participated in this research during a science camp. Pre-and post-test included open questions and drawing tasks. The campers' drawings were analyzed to assess their out-of-school perceptions related to SI. The aim was to clarify what phases and factors the campers associated with SI in nature, and how their perceptions differ after participating at a science camp. The findings suggest that the phases of SI were well known before the camp, but minor developments in campers' perceptions of the phases of SI did occur. In the drawing analysis, symbols from a range of areas were identified. The symbols most frequently referred to the natural environment. The drawings in the post-test were generally more detailed than those in the pre-test. In particular, symbols of technology and laboratory equipment appeared more frequently after the science camp.
\end{abstract}




\section{INTRODUCTION}

\section{Out-of-school learning}

Learning science outside of school is a theme that interests adolescents. Although learning processes in science are similar both in and out of school, there may be differences in what is learned (Rennie, 2007). Braund and Reiss (2006a, 2006b) mentioned five ways in which out-of-classroom contexts can improve the learning of science: (1) improved development and integration of concepts, (2) extended and authentic practical work, (3) access to rare material and to "big" science, (4) attitudes to school science, including stimulating further learning, and (5) social outcomes, including collaborative work and responsibility for learning.

Out-of-school contexts can stimulate adolescents to think more deeply about science and provide new connections with the field (Braund \& Reiss, 2006a). A learning environment outside of formal education supports chemistry learning by providing learners with a wide range of experimental methods (Nuora, 2016). It helps them deepen their knowledge of things they have learned previously. Rennie (2007) observed that many out-of-school activities have a short duration. This affects the impact of those experiences, meaning it may come later. Scientific research that is performed in an outof-school context may also increase adolescents' motivation and enthusiasm to learn science. Uitto, Juuti, Lavonen and Meisalo (2006) investigated Finnish 15-year-old pupils and their interest in biology and their out-of-school experiences. They found that out-of-school experiences were the most important factor affecting the interest in biology.

Juuti, Lavonen, Uitto, Byman and Meisalo (2010) suggest that it is important to discover groups of students who prefer certain teaching methods because students evaluate differently teaching methods used in science (chemistry and physics). They also summarize the implications of their study for teaching. In order to enhance positive feelings in the science classroom, teachers should, for example, use (1) more out-of-school connections, (2) more discussion on difficult concepts, (3) less teacher presentation of the content on the blackboard, (4) less reading of textbooks, (5) more discussion (especially for girls) and (6) for interested students more group projects and creative activities. Karacam (2015) stated that an inquiry approach leads to positive perceptions since it allows adolescents to conduct research and feel like scientists.

Dabney et al. (2012) studied out-of-school science activities and their association with career interest in science, technology, engineering, and mathematics (STEM). Their research results indicate that students' participation in out-of-school activities plays a significant role in university career interest in STEM. In addition, students' middle school interest in science and mathematics has a big role in university career interest in STEM. It is important to concentrate on middle school students because these years are crucial for cultivating students' interest in STEM careers (Moreno, Tharp, Vogt, Newell \& Burnett, 2016).

Fägerstam and Blom (2013) observed that teaching and learning outside the classrooms is not common in Swedish schools. Despite this lack, their research data suggest that outdoor lessons have a positive impact on the pupils' motivation and interest. Osborne and Dillon (2008) have made recommendations on how EU countries can improve science education. According to them, EU countries should ensure that science teachers are of the highest quality, and the emphasis in science education before age 14 should be on engaging students with science and scientific phenomena. Osborne and Dillon (2008) also suggested that this is best achieved through opportunities for extended investigative work and hands-on experimentation.

\section{Hands-on experimentation}

Broman and Simon (2015) studied a group of Swedish upper secondary school chemistry students $(N=495)$ and their ideas about how to improve their chemistry experience. When analyzing what would improve that experience, students suggested being more practical, more student centered and making it relevant to everyday life. Holstermann, Grube and Bögeholz (2010) studied whether 141 
students from the 11th grade with experience in specific hands-on activities show higher interest in these activities than do students without such experience. The relationship between interest in the respective activity and the quality of the hands-on experience was also examined. In total, 28 typical hands-on activities in biology education were categorized as follows: (1) experimentation, (2) dissection, (3) work with microscopes, and (4) classification. As mentioned, activities tend to benefit from being hands-on. Holstermann et al. (2010) indicated that the performance of various hands-on activities can influence students' interest differently. In fact, for most hands-on activities they found no effect on interest. Their research also stated that the quality of hands-on experiences showed positive correlations with interest in the respective hands-on activities. Hands-on labs have the following educational goals: conceptual understanding, design skills, social skills and professional skills (Ma \& Nickerson, 2006).

Young (2002) noted that hands-on activities must be explicitly supplemented with reflective observation and abstract conceptualization - so-called "minds-on" exercises - to complete the learning cycle. These types of exercises provide meaningful conceptual understanding. Concrete experience is important because it builds a foundation for the learning process. It should also be designed to motivate, engage and evoke the affective aspect of experience. Concrete experiences help bridge students' perceived gap between the real world and their academic learning. The emphasis is on going through the use of concepts, theories or processes to create practical outcomes. Young (2002) argues that active experimentation should change inactive learners into active and involved learners. Ornstein (2006) emphasizes that in order to positively influence student attitudes in hands-on laboratory activities, the activities need to be interesting and relevant to the students' courses. This requires several levels of change, including the need for all teachers to recognize the importance of independent inquiry and laboratory activities. That will influence both students' attitudes toward science and the academic atmosphere. It is important that teachers are trained in how to include hands-on laboratory activities in science classes throughout middle school and high school. On the other hand, it is critical that teachers incorporate independent inquiry and meaningful hands-on activities into their curriculum on a fundamental, regular basis.

\section{Scientific inquiry}

Scientific inquiry (SI) is widely accepted as a method of science teaching (Leblebicioglu et al., 2017) and it also is the centerpiece of science teaching (Antink-Meyer, Bartos, Lederman \& Lederman, 2014; Williams, Ma, Prejean, Ford \& Lai, 2007). Scientific knowledge, including developing, accepting, and utilizing scientific knowledge, is constructed by using SI in teaching (Leblebicioglu et al., 2017; Schwartz, Lederman \& Crawford, 2004). According to Tang, Coffey, Elby and Levin (2009), some associate SI with hands-on learning or activity-based instruction; others treat SI as process skills linked with the scientific method. Tang et al. (2009) also reported that many science educators argue that SI should focus on the thinking practices through which students understand and construct scientific practices. These include mechanistic and model-based reasoning, scientific argumentation, and sense making.

Hofstein, Kipnis and Abrahams (2013) highlight that asking relevant and scientifically oriented questions is an integral part of SI (e.g., Chin \& Osborne, 2008). Hofstein et al. add that the formulation of a good question is at the heart of what science is all about. For example, questions from students indicate that (1) they have been thinking about the ideas presented, and (2) they have been trying to link them with other things they know (Chin \& Osborne, 2008). At science camps, it is typical that almost all of the aforementioned phases of SI take place in experimental work. With SI, it is also possible to develop an understanding of the nature of science in students.

In this paper, SI refers to the traditional science processes such as observing, inferring, classifying, predicting, measuring, questioning, interpreting and analyzing data (cf. Antink-Meyer et al., 2014). SI also refers to the combination of these processes with scientific knowledge, scientific reasoning and critical thinking to develop scientific knowledge (Lederman, Antink \& Bartos, 2014). 


\section{Open inquiry, guided inquiry and structured inquiry}

Inquiry-based teaching and learning can be divided into three sub-sections, depending on the extent of autonomy given to students: (1) student-directed open inquiry, (2), teacher-directed guided inquiry, and (3) teacher-directed structured inquiry (Zion \& Mendelovici, 2012). Open inquiry is the most complex level of inquiry-based learning. According to Zion and Mendelovici (2012), open inquiry allows the students to select a wide variety of inquiry questions, and approaches. This kind of inquiry both reflects and simulates the type of research and experimental work that is performed by scientists. It also demands high-order thinking capabilities like questioning, designing an experimental array, critical thinking and reflection. Teacher-directed guided inquiry means that students investigate questions and procedures that a teacher gives them. The students themselves decide the processes to be followed. In addition, the students decide the solutions to be targeted. In guided inquiry, students work collaboratively solving inquiry questions and procedures that are provided by the teacher. This decreases the level of uncertainty during the inquiry process. The last form of inquiry is teacher-directed structured inquiry, in which the students investigate a teacher-presented question through a prescribed procedure. They receive explicit guidelines at each stage, leading to a predetermined outcome. This approach has been criticized as resembling the following of a recipe. However, Zion and Mendelovici (2012) have argued that in this kind of inquiry, students make handson investigations and they have an opportunity to develop basic inquiry skills: making observations, raising hypotheses, collecting data, drawing conclusions, making inferences and finding solutions.

All forms of research inquiries can be used, depending on the situation, in science camps. The choice is influenced by the research task, the student's experience, knowledge, skills and age. The most common form of the inquiry in science camp was teacher-directed inquiry, because we did not know the campers before.

\section{PURPOSE OF THE STUDY}

Science camp at the Konnevesi Research Station is a three-day camp for the adolescents who are interested in natural sciences. Konnevesi Research Station belongs to the Department of Biological and Environmental Science at University of Jyväskylä, Finland. (Konnevesi Research Station) Topics of science camp include nature, water and the environment. The themes are closely related to the nature surroundings of the research station. Out-of-school learning is fulfilled in this camp and it includes experimental research work.

Our study addressed the following research question: What differences can be observed for adolescents regarding phases and factors associate with scientific inquiry in nature after participating at a science camp? We analyzed adolescents' views before and after a science camp.

The theoretical basis of the research is in hermeneutic phenomenology. According to Kafle (2011) hermeneutic phenomenology is focused on a subjective experience of individuals. Also, it is concerned with the life world or human experience as it is lived (Laverty, 2003). Hermeneutic phenomenology reveals the uniqueness of common practices and shared meanings that can inform the way people think about their practice.

The next section addresses the study methodology, participants, data collection, data analysis and reliability. These are followed by a presentation of our results and conclusions.

\section{METHOD}

The purpose of the science camp was to introduce science and SI in nature to adolescents. The data in this research were obtained from the adolescent campers who participated in a three-day science camp in summer 2017. The science camp team consisted of university teachers and chemistry teacher-students. The adolescents interacted with them throughout the camp. The campers attended the science camp voluntarily. 


\section{Contents of the science camp at Konnevesi Research Station in 2017}

The science camp's main themes were soil and water research.

These themes were addressed at the camp using the following experimental work:

Examination of insects

Isolation of plant colorants

Water permeability

Water purification: water filtrations, precipitation, alkalization and activated carbon filtering

Study of a lake water sample: $\mathrm{pH}$ and oxygen content, studying with microscope

Examination of soil layers and humidity

Soil pH measurement

Preparing forestland soil for growing vegetables

Amazing Race: a race where the natural science experiments are carried out at control points

The science camp was conducted over three days at Konnevesi Research Station, which is located next to a forest and the lakeside. One of the aims of the camp was to develop collaboration skills, so the campers worked mostly in small groups of three to six in a camp. However, they used a personal drawing in data collection phase.

\section{Participants}

A total of 11 campers at the science camp participated in this study and they used a personal drawing. The voluntary nature of participation was emphasized. No adolescents declined to take part. The average age of the campers was 14.8 years (range $14-16), 7$ th grade $=5(45 \%)$, 8 th grade $=3(27 \%)$, and 9 th grade $=3(27 \%)$. This study did not focus on gender differences. The campers were asked if they had previously performed SI outside the classroom. Six $(6 / 11,55 \%)$ said they had not done so, but five $(5 / 11,45 \%)$ said they had.

\section{Drawings as a research method}

In this research has been used drawings as a research method. The advantages of using drawings as research material are that they provide a non-verbal expression, and they are visual data that can give insight into how a person views an issue (Einarsdóttir, 2007). Guillemin (2006) argues that, methodologically, drawings are both visual products and produce meanings. She also states that drawings are not stable or fixed entities: they are produced in a particular space and time. Drawings make it possible to understand how people see their world (Guillemin, 2006), and they are often used to obtain an idea of children's conceptions (Ehrlén, 2009). Guillemin (2006) suggests that, for reasons of validity, drawings as a research method work best as an adjunct to other research methods. Qualitative methods, like drawings, diaries and photography, are seen as more effective in enabling children to communicate in their own terms (Barker \& Weller, 2003).

When drawings are used as a research method, it is important to consider that not all adolescents are confident about their talent for drawing. Some people, as pointed out by Einarsdóttir (2007), simply do not like to draw. It is important that adolescents know the focus is on the content of their drawing, not on its quality (see Mitchell, Theron, Stuart, Smith \& Campbell, 2011). According to Punch (2002), the drawings themselves are rich visual illustrations that directly show how children see their world. However, especially older children may not consider drawing to be a fun method. It is therefore important to motivate them to draw a picture of a desired theme.

\section{Data collection}

In this study, data were collected with questionnaires and drawings. The data were collected in 2017 and translated into English. All the campers had parental permission to participate in this study. Also, the campers had a chance to refuse to participate in the study. However, all the campers participated in the study. The campers were clearly informed where and how the research material would be used. The background information consisted of the year of birth, class, if adolescents had previously done 
experiments in nature, and a Likert scale question regarding the interest in studying natural sciences. The campers were asked to include their names on the research paper because we wanted to combine both pre- and post-tests with each other in analysis phase. The names were changed to pseudonyms.

Adolescents were asked to answer the following open question: "Write in as much detail as you can on which phases you think belong to scientific inquiry." Questionnaire included only this one question and it wasn't published earlier. Because we constructed our own questionnaire, we piloted it on participants who were representative of our definitive sample. This measure helped to ensure that the question was correctly understood. Open question was used because we wanted to confirmation to the interpretation of the drawings. The campers drew a picture based on the following instructions: "Draw a picture of what kind of scientific inquiry you think you can do in nature. It can be a single image or it may consist of different sections." The participants had a chance to use colors in their drawings.

All the participants drew an image on a given theme which wasn't one of the science camp's main theme. Some of them described the image by adding text to the drawing. Adolescents had 20 to 30 minutes to complete their drawings, which seemed adequate for them to fully respond to the research. At the end of the science camp, the adolescents were asked to answer to the same open question. The same drawing instructions were also given. Pre- and post-test results were compared and interpreted to find out differences in phases and factors associating with scientific inquiry in nature. A further aim was to see what kind of issues emerged from the drawings.

\section{Data analysis and quality measurements}

Both quantitative and qualitative approaches were used in the data analysis. First, the researchers agreed on a list of the phases of SI (Näsäkkälä, Flinkman \& Aksela, 2001, p. 27). We used a literature list of the phases of Si to compare campers' responses. At the source of Näsäkkälä et al. (2001), the research phases have been described from the point of view of school education in Finland. Researchers then analyzed which phases were mentioned in campers' answers. A directed content analysis was conducted. The answers were categorized out from the list of phases of SI that were presented previously. The number of entries were summed up both from the pre- and post-test and the results were compared. In this study, the analysis included direct quotations from open responses in order to provide additional explanations for the answers.

After their analysis of the drawings, the researchers made a table that contained the symbol groups from the drawings. The symbols in this research were based on earlier research that focused on the effect of informal and formal interaction between scientists and children at a science camp on the children's images of scientists (see Leblebicioglu, Metin, Yardimci \& Cetin, 2011). The symbols were modified to answer the requirements of this study and to reflect the variety of the drawings. All the drawings were analyzed independently by three researchers. The symbols of the campers' drawings were coded, and then the frequencies and percentages of each code were determined. All of the researchers have strong backgrounds in chemistry and chemistry education. The results of each analysis were compared, the few disagreements that emerged were resolved through discussion, and a final decision about the analysis was made.

The validity of a study refers to how the research results correspond to the actual state of facts, while a study's reliability refers to the extent to which random factors potentially affected the results of the research (Tuomi \& Sarajärvi, 2013). In our descriptions of the reports of the campers we have aimed at fairness. This has been done by trying to treat the campers and their answers and drawings equally. Additionally, all stages of the research process have been introduced as accurately as possible to give the reader a clear idea of their content. The independent analyses of three researchers and the common conclusions reached after discussions also add to the reliability of the analysis. In a consensus-based theory of truth, people can create truth by arriving at a consensus (Patton, 2015; Tuomi \& Sarajärvi, 2013). 
To increase the validity of the research, critical aspects in the data were highlighted. The use of multiple coders in the research analysis phase may be seen as a form of triangulation. This study also used qualitative and quantitative methods of triangulation. Triangulation is seen as adding validity (Patton, 2015; Tuomi \& Sarajärvi, 2013). It should be noted that discussions with the campers and the science camp program could have influenced their drawings and their explanation in the post-test. However, because the size of the research sample is small, generalizations cannot be made.

\section{RESULTS AND INTERPRETATION}

The campers' images of SI in nature were examined both at the beginning and at the end of the science camp through an open question and drawings. The names in the quotes are pseudonyms and the number in parentheses corresponds to the frequency of the related code. In the analysis of the answers to the open question, the campers' answers were classified into different categories.

\section{Analysis of the phases of the scientific inquiry}

Table 1 presents the categorization of the data on the campers' perceptions of SI at the beginning and at the end of the camp. This section provides quotations from the answers the campers gave to the following question: "Write in as much detail as you can on which phases you think belong to scientific inquiry." First, researchers determined what phases belong to SI (see Table 1). Pre- and post-test $n$ indicate the number of campers who included that specific phase as part of SI in their own responses. For example, all of the campers in the study mentioned content related to the implementation of research in both the pre- and post-tests.

Table 1. Categorization of the data on the campers' perceptions of SI at the beginning (pre-test) and end (post-test) of the science camp, 11 respondents

\begin{tabular}{|c|l|c|c|}
\hline \multicolumn{1}{|c|}{ Phase of the scientific inquiry } & $\begin{array}{c}\text { Pre-test } \\
\mathbf{n}\end{array}$ & $\begin{array}{c}\text { Post-test } \\
\mathbf{n}\end{array}$ \\
\hline $\mathbf{1 .}$ & Subject choice & 5 & 4 \\
$\mathbf{2 .}$ & Preliminary observations and background information & 2 & 3 \\
\hline $\mathbf{3 .}$ & Creating a hypothesis & 2 & 2 \\
\hline $\mathbf{4 .}$ & Research planning & 5 & 4 \\
\hline $\mathbf{5 .}$ & Implementation of research & 11 & 11 \\
\hline $\mathbf{6 .}$ & Processing of results & 2 & 3 \\
\hline $\mathbf{7 .}$ & Making conclusions & 3 & 5 \\
\hline $\mathbf{8 .}$ & Evaluation of results & 4 & 5 \\
\hline $\mathbf{9 .}$ & Presenting of results & 1 & 1 \\
\hline Total & & 35 & 38 \\
\hline
\end{tabular}

Here are some remarks to the particular phases which were somewhat unfocused (Table 1). Phase 1, subject choice, included a variety of studies within the same subject area, or the response somehow referenced decision-making. Phase 2, preliminary observations and background information, included different kinds of information collecting. Phase 5, implementation of research, included the subjects, instruments and equipment. Phase 6, processing of results, included a clear statement that is carried out on the results (e.g. an analysis such as averaging). Phase 8, evaluation of results, included comparing your own results with other studies and seeing that the results corresponded with reality. This phase also included comparing the results to the hypothesis. 
Table 2. Symbols used by campers in their drawings.

\begin{tabular}{|c|c|c|c|}
\hline Symbols, pre-test & Symbols, post-test & $\begin{array}{l}\text { Pre-test } \\
\mathrm{n}(\%)\end{array}$ & $\begin{array}{l}\text { Post-test } \\
\text { n (\%) }\end{array}$ \\
\hline Symbols of the natural environment & & $81(64)$ & $86(56)$ \\
\hline 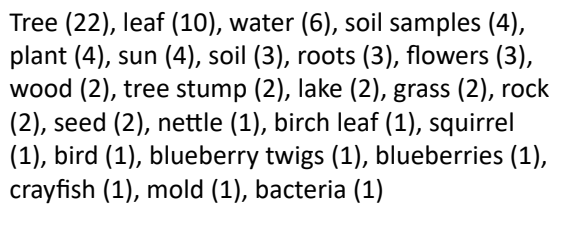 & 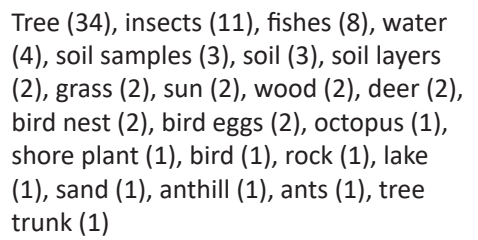 & & \\
\hline Symbols of laboratory equipment & & $9(7)$ & $24(16)$ \\
\hline $\begin{array}{l}\text { Test tubes (5), pipette (1), beaker (1), spoon (1), } \\
\text { pH paper (1) }\end{array}$ & $\begin{array}{l}\text { Beaker (8), Petri dish (3), test tubes (2), } \\
\text { sample dish (2), pH paper (1), funnel (1), } \\
\text { glass rod (1), lab coat (1), boiling flask } \\
\text { (1), filter (1), filter material (1), spray } \\
\text { bottle (1), Bunsen burner (1) }\end{array}$ & & \\
\hline Symbols of biology content & & $10(8)$ & $9(6)$ \\
\hline $\begin{array}{l}\text { Examination of plants (2), identification of plant } \\
\text { species (1), examination of properties of a plant } \\
\text { (1), photosynthesis (1), examination of wood } \\
\text { (1), investigating the variation in the number of } \\
\text { trees (1), examination of micro-organisms (1), } \\
\text { examining trees (1), examination crabs (1) }\end{array}$ & $\begin{array}{l}\text { Examination of micro-organisms ( } 2 \text { ), } \\
\text { examination of plants (1), examination } \\
\text { of water sample (1), examination of } \\
\text { wood (1), investigating the variation in } \\
\text { the number of trees (1), identification of } \\
\text { animal species (1), insect research (1), } \\
\text { animal observation (1) }\end{array}$ & & \\
\hline Symbols of chemistry content & & $6(5)$ & $12(8)$ \\
\hline $\begin{array}{l}\text { Soil analysis (2), determination of soil acidity (1), } \\
\text { pH determination (1), compounds (1), examina- } \\
\text { tion of rock composition (1) }\end{array}$ & $\begin{array}{l}\text { Soil analysis ( } 2 \text { ), heat transfer ( } 2 \text { ), filte- } \\
\text { ring ( } 2 \text { ), water analysis ( } 2 \text { ), examination } \\
\text { of rock composition (1), pH determina- } \\
\text { tion (1), soil humidity analysis (1), flame } \\
\text { colors (1) }\end{array}$ & & \\
\hline Symbols of technology & & $5(4)$ & $13(8)$ \\
\hline $\begin{array}{l}\text { Magnifying glass (3), binoculars (1), microscope } \\
\text { (1) }\end{array}$ & $\begin{array}{l}\text { Magnifying glass (2), microscope (2), } \\
\text { sun boiler ( } 2 \text { ), soil humidity sensor ( } 2 \text {, } \\
\text { binoculars (1), data logger (1), diving } \\
\text { equipment (1), insect trap (1), camera } \\
\text { (1) }\end{array}$ & & \\
\hline Symbols of knowledge & & $6(5)$ & $3(2)$ \\
\hline $\begin{array}{l}\text { Observation (1), book (1), chemical formulas (1), } \\
\text { diagram (1), notes (1), research report (1) }\end{array}$ & Book (2), diagram (1) & & \\
\hline Others & & $9(7)$ & $7(5)$ \\
\hline $\begin{array}{l}\text { Bucket (1), presenting results }(1) \text {, table }(1) \text {, chair } \\
(1) \text {, boat }(1) \text {, fish trap (1), oars (1), outboard mo- } \\
\text { tor (1), repetition of research experiments (1) }\end{array}$ & $\begin{array}{l}\text { Foil (2), table ( } 2) \text {, cardboard box (1), } \\
\text { repetition of research experiments (1), } \\
\text { cool box (1) }\end{array}$ & & \\
\hline Total & & $126(100)$ & $154(100)$ \\
\hline
\end{tabular}

There were no remarkable differences between the phases in pre- and post-tests as a whole although dispersion was observed in individual answers (Table 1). A minor shift in thinking towards a more advanced direction occurred in phases 2, 6, 7 and 8 (see Table 1). In phases 1 and 4, however, a change in the other direction occurred. Overall, no major changes were found in the pre- and post- 
tests. There were only slightly more descriptions of the phases of inquiry in the post-test than in the pre-test (n (total in pre-test) $=35 \rightarrow \mathrm{n}$ (total in post-test) $=38$ ).

\section{Analysis of the symbols}

In the second phase of our study we analyzed the drawings. The campers were instructed as follows: "Draw a picture of the kind of scientific inquiry you think you can do in nature. The image may be uniform or it may consist of different sections." Any symbols identified in our analysis of the drawings were classified into various categories. Symbols of SI in nature included laboratory equipment, the natural environment, biology content, chemistry content, knowledge, and technology (Table 2). The total number of mentions of different symbols in the drawings were calculated.

In all, there were 126 symbols in the pre-test drawings and 154 in the post-test drawings. The results revealed that symbols of natural environment were the most common type of symbols in the campers' pre-test drawings $(n=81)$ as well as in the post-test drawings $(n=86)$. Trees were the most common natural environment symbols in the campers' drawings. As an interesting feature, insects appeared in the post-test but not in the pre-test. This addition could be attributed to the part of the science camp program that included investigating insects with a microscope.

In addition, there were more symbols of laboratory equipment (e.g. beakers, Petri dishes, test tubes and $\mathrm{pH}$ paper $)$ in the post-test drawings $(n=24)$ than in the pre-test ones $(n=9)$. A beaker was the most common laboratory equipment symbol. The amount of technology symbols increased from the pre-test $(n=5)$ to the post-test $(n=13)$. A magnifying glass, binoculars and microscope appeared in both tests. A sun boiler, a soil humidity sensor, a data logger, diving equipment, an insect trap and a camera were present only in the post-test drawings. These instruments, except for diving equipment, were used in the experimental research in the science camp.

Symbols of chemistry content comprised from 6 of the pre-test symbols to 12 of the post-test ones. The post-test symbols related mainly to the content of the science camp. Symbols such as heat transfer, filtering, water analysis, soil humidity analysis and flame colors all appeared. Biology content symbols, which varied significantly, were present in 10 of the pre-test drawings and 9 of the post-test, meaning the findings from the pre- and post-tests were quite similar. On the other hand, an interesting result was that there were more knowledge symbols in the pre-test $(n=6)$ than in the post-test $(n$ $=3$ ). Only books and diagrams were mentioned in the post-test in this category.

Overall, the total number of symbols increased from the pre-test $(n=126)$ to the post-test $(n=154)$, which is a positive result. The increase suggests that the science camp has had an impact on the campers and that they have learned new content about science experimentation. Several pieces of laboratory and technical equipment became familiar to the science campers and were included in the posttest drawings. The campers also experienced a new kind of inquiry during out-of-school learning. As mentioned before, $55 \%$ of the campers said they had no experience of inquiry outside the classroom before coming to the science camp.

\section{Analysis of individual drawings}

In the third phase of our study we examined the results of the drawings in more detail. In the following analyses $a$ refers to the pre-test drawing and $b$ to the post-test drawing. Drawing pairs (e.g. 7a and 7b) were made by one camper. When investigating changes in the drawings of an individual camper, most of the changes were in the subject of the images. The subjects related mainly to the content of the camp in the post-test. In this section we present selected examples of campers' drawing pairs that showed noteworthy changes between pre- and post-test.

The first pair of drawings ( $5 \mathrm{a}$ and $5 \mathrm{~b}$, Figure 1) contains a number of aspects (see also Table 2). Both drawings include various kinds of inquiry performed in nature and in the laboratory. The pre-test drawing contains a leaf being studied with a microscope as well as a plant growth process and the 
reaction equation of photosynthesis. The post-test drawing, however, shows new topics and methods, including water analysis, insect screening, and soil analysis. Water and soil analysis were both part of the science camp. More environmental observation is seen in the post-test drawing than in the pre-test one, which includes tests that can be done in class. The types of observation presented also differ. The change in camper's perceptions of SI showed in his/her answers to open questions (see Table 1). The open response contained several phases of inquiry in both the pre- and post-tests. In the pre-test the camper mentioned four inquiry phases and in the post-test six phases. The pre- and posttest answers contained mention of the possibility that an inquiry may not be successful. The post-test answer clearly showed the cyclical nature of research compared to the pre-test. The following is an excerpt from one post-test answer:

Before the inquiry, a hypothesis should be made. For the research, you need to get enough information about the subject to be studied to make it easier to do research (this will make it easier for you to get the optimum results). If the study contains precise measurements, it should be repeatedly performed to avoid errors. Finally, we can compare the hypothesis and the outcome. If the end result is not desired, then you think about what went wrong and resume the inquiry. (5b)

$5 a$

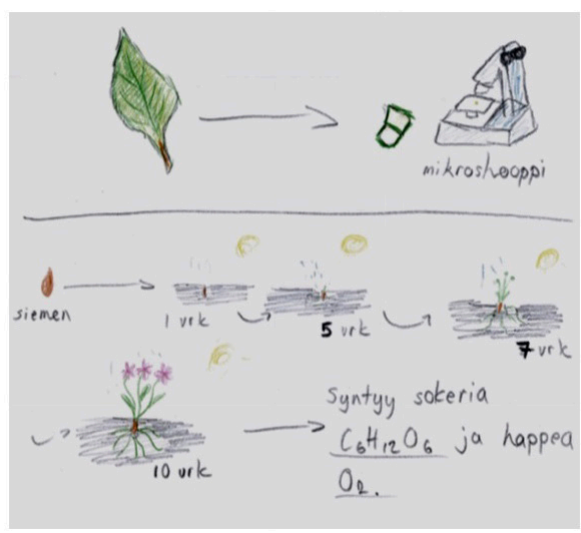

$5 b$

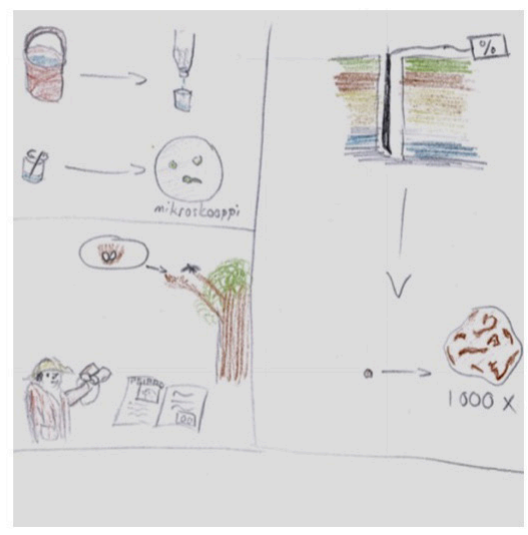

Figure 1. Drawing pair $5 a$ and $5 b$. The pre-test drawing (5a) contains the words seed and microscope along with a depiction of the growth of the seed into a plant. The post-test drawing (5b) contains the word microscope.

The second drawing pair ( $3 a$ and $3 b$, Figure 2) focuses on research results. The subject of the drawing changes. In the pre-test drawing an inquiry related to the characteristics of the species is presented while the post-test drawing includes a sun boiler. Sun boiler was included in the Amazing Race competition. His/her answer to the pre-test was much wider than in the post-test: it consisted of five phases of inquiry (see Table 1). The post-test answer included only two inquiry phases: preliminary observations and background information and carrying out the research. Here is the pre-test answer to the open question:

I believe that SI includes:

- the subject of the study (e.g. an animal)

- background information on the subject of the study

- the subject of study

- research place

- proper research tools

- conducting research often to obtain reliable information (3a) 
$3 a$

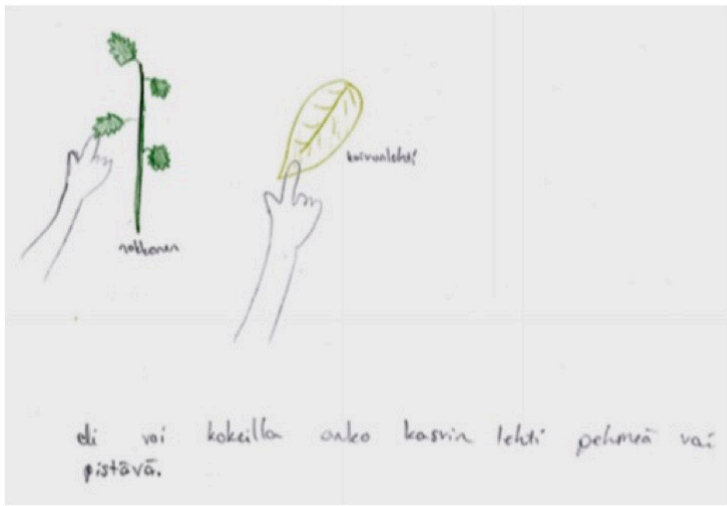

3b

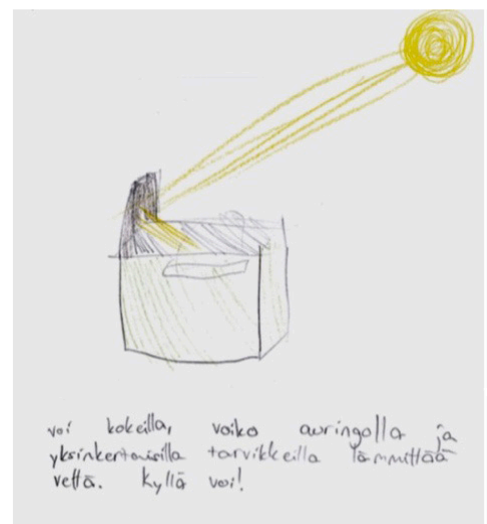

Figure 2. Drawing pair $3 a$ and $3 b$. The text in the pre-test drawing (3a) states "You can try if the leaf is soft or stinging." In the post-test drawing ( $3 b)$, the text states "You can try out if the sun and simple accessories can warm water. Yes, you can!”

The next drawing pair presents a clear change (8a and 8b, Figure 3). The pre-test focused on observation of crabs and the composition of rock. The pre-test drawing presents a direct research question: "What does the rock consist of?" The subject of the post-test drawing are again the composition of rock, some laboratory research and the identification or study of birds. The post-test included reflection, repetition and a description of the process. There is an experimental approach and the image depicts a laboratory-type situation. The post-test drawing also contains more research than the pretest drawing does. The open questions, however, showed no remarkable changes in pre- and post-test answers (Table 1). Both answers displayed a range of research methods and testing. Conclusions were also mentioned.

Here is the pre-test answer to open question:

Natural SI involves collecting samples and information. Based on the knowledge, a theory can be made that will be tested. Natural SI also includes diverse research methods. The more samples that can be collected, the better. (8a)

$8 a$
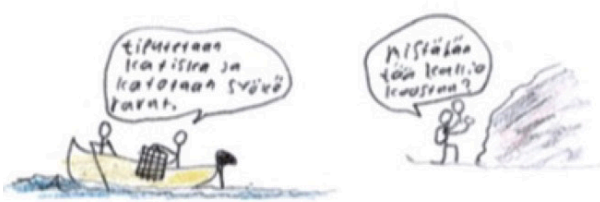

8b

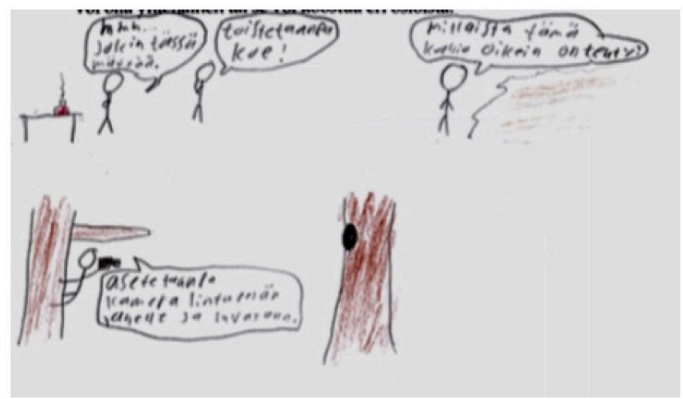

Figure 3. Drawing pair $8 a$ and $8 b$. The text in the pre-test drawing (8a) states "Let's drop a fish trap and see if the crabs go there" and "I wonder what this rock is made of". In the post-test drawing (8b), the text states "Hmm... Something is wrong", "Let's do this experiment again!", "I wonder what this rock is made of", and "Let's place the camera close to the bird's nest and photograph it". 
In the final drawing pair (11a and 11b, Figure 4) the style of the illustration does not change. Both drawings are simple and the post-test topic links up directly to the content of the science camp. Water analysis appears in the pre-test drawing, and soil analysis in the post-test drawing. In both drawings the research object is the environment. The post-test drawing indicates that the camper's knowledge of technology has evolved, with the later drawing depicting a measuring device. It was interesting to note that the pre- and the post-test answers to the open questions resembled each other (Table 1). They included the choice of subject, research planning and carrying out the research. Both responses emphasized the relevance of motivation to the topic being studied. The camper stated that the research topic should be interesting. Here is the post-test answer to open question:

A good place to do the research and the necessary tools. Interest and enthusiasm for natural sciences. The subject of the study. (11b)

$11 \mathrm{a}$

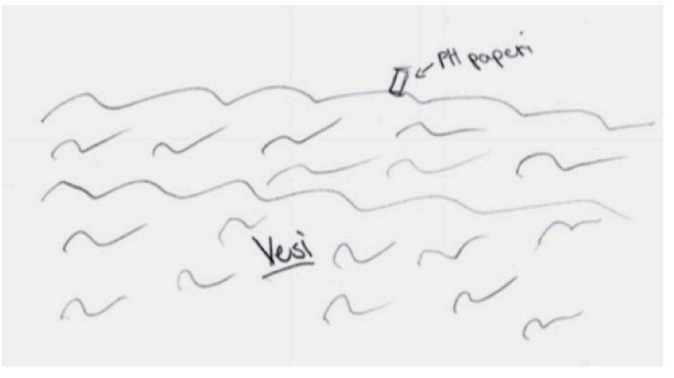

$11 b$

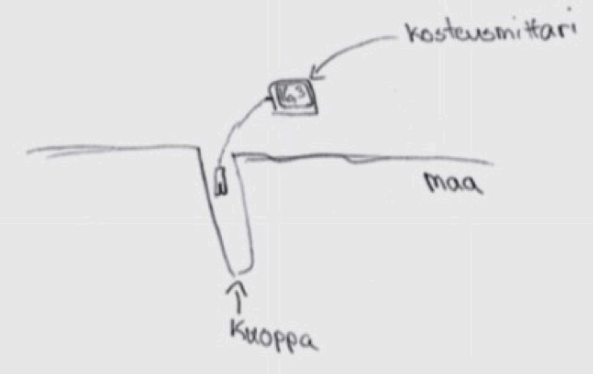

Figure 4. Drawing pair 11a and 11b. The labels in the pre-test drawing (11a) are $p H$-indicator paper and water. The labels in the post-test drawing (11b) are hygrometer, soil and hole.

\section{DISCUSSION AND CONCLUSIONS}

The present study aimed to find out what phases adolescent campers attending a science camp associated with SI in nature. We wanted to find out what differences can be observed for adolescents regarding phases and factors associate with scientific inquiry in nature after participating at a science camp. The responses indicated that the phases of SI were relatively well known. The best-known phases were implementation of research, subject choice, research planning, evaluation of results and making conclusions. This is a positive result because it says that the campers have learned these phases at school or somewhere else before coming to the camp. Also, the campers were interested in science, so, this may have affected to the outcome. The less familiar phases of SI surprisingly included presenting of results and creating a hypothesis, even though these are universally featured phases of SI in Finnish lower secondary school chemistry education.

A comparison of the data at the beginning and the end of the science camp indicates some improvements in the campers' perceptions of SI in nature. Table 2, in particular, shows that there were some positive qualitative developments from the pre-test to the post-test. The post-test also resulted in more detailed drawings than the pre-test did (cf. Metin \& Leblebicioglu, 2011). Only $45 \%$ of the campers had previous experience of inquiry outside the classroom before coming to the science camp. However, the small sample size prevents any generalizations from being made.

The drawings of the campers contained a wide range of symbols for SI. Symbols of the natural environment were the most common, probably due to the fact that nature is an obvious research subject in the context of this study. The campers clearly adopted the idea of nature as a research subject. Some drawings showed that the campers had realized the cyclic nature of research. Experimental SI 
was clearly familiar to the campers. The interest in science was visible, which was why young people came to the science camp (e.g. Nuora, 2016). According to Nuora (2016), the majority of campers felt that chemistry is most sensibly studied through experimentation, and interesting experimental works deepened the knowledge of chemistry and biology. The results of this research show that SI is an inherent part of natural science. Yet it is good to remember that the quality of hands-on experiences is an important motivating factor (e.g. Holstermann et al., 2010).

Different categories of symbols were identified in the drawings (Table 2). We wanted to use symbols instead of reasoning of ideas because we wanted to know the influence and its intensity of science camp on changing campers' ideas. More than half of the symbols described the natural environment in both the pre- and post-tests. However, symbols were found from a range of areas. Symbols for technology and laboratory equipment came directly from the task topics. These have clearly remained in the campers' memories. The amount of the symbols for technology and laboratory equipment increased as young people used new devices and equipment at the science camp.

According to Fägerstam and Blom (2013), studies on outdoor learning in biology are most often conducted at specific places away from ordinary school surroundings. Therefore, they suggest, it is not surprising that learning outcomes are well remembered by the students afterwards. This phenomenon was also visible in our science camp research. And because there are only a few studies concerning outdoor learning as part of ordinary school work, it would be important to study it further (see Fägerstam \& Blom, 2013).

\section{REFERENCES}

Antink-Meyer, A., Bartos, S., Lederman, J. S., \& Lederman, N. G. (2014). Using science camps to develop understanding about scientific inquiry - Taiwanese students in a U.S. summer science camp. International Journal of Science and Mathematics Education, 14(1), 29-53. doi:10.1007/s10763-014-9576-3

Barker, J., \& Weller, S. (2003). "Is it fun?” developing children centred research methods. International Journal of Sociology and Social Policy, 23(1/2), 33-58. doi:10.1108/01443330310790435

Braund, M., \& Reiss, M. (2006a). Validity and worth in the science curriculum: Learning school science outside the laboratory. The Curriculum Journal, 17(3), 213-228. doi:10.1080/09585170600909662

Braund, M., \& Reiss, M. (2006b). Towards a more authentic science curriculum: The contribution of out-of-school learning. International Journal of Science Education, 28(12), 1373-1388. doi:10.1080/09500690500498419

Broman, K., \& Simon, S. (2015). Upper secondary school students' choice and their ideas on how to improve chemistry education. International Journal of Science and Mathematics Education, 13(6), 1255-1278. doi:10.1007/s10763-014-9550-o

Chin, C., \& Osborne, J. (2008). Students' questions: A potential resource for teaching and learning science. Studies in Science Education, 44(1), 1-39. doi:10.1080/03057260701828101

Dabney, K. P., Tai, R. H., Almarode, J. T., Miller-Friedmann, J. L., Sonnert, G., Sadler, P. M., \& Hazari, Z. (2012). Out-of-school time science activities and their association with career interest in STEM. International Journal of Science Education, Part B, 2(1), 63-79. doi:10.1080/215484 55.2011.629455

Ehrlén, K. (2009). Drawings as representations of children's conceptions. International Journal of Science Education, 31(1), 41-57. doi:10.1080/09500690701630455

Einarsdóttir, J. (2007). Research with children: methodological and ethical challenges. European Early Childhood Education Research Journal, 15(2), 197-211. doi:10.1080/13502930701321477 
Fägerstam, E., \& Blom, J. (2013). Learning biology and mathematics outdoors: effects and attitudes in a Swedish high school context. Journal of Adventure Education and Outdoor Learning, 13(1), 56-75. doi:10.1080/14729679.2011.647432

Guillemin, M. (2006). Understanding Illness: Using Drawings as a Research Method. Qualitative Health Research, 14(2), 272-289. doi:10.1177/1049732303260445

Hofstein, A., Kipnis, H., \& Abrahams, I. (2013). How to learn in and from the chemistry laboratory. In I. Eilks \& A. Hofstein, (Eds.) Teaching Chemistry - A Studybook: A Practical Guide and Textbook for Student Teachers, Teacher Trainees and Teachers, (pp. 153-182). Rotterdam: Sense Publishers. doi:10.1007/978-94-6209-140-5_6

Holstermann, N., Grube, D., \& Bögeholz, S. (2010). Hands-on activities and their influence on students' interest. Research in Science Education, 4O(5), 743-757. doi:10.1007/s11165oo9-9142-0

Juuti, K., Lavonen, J., Uitto, A., Byman, R., \& Meisalo, V. (2010). Science teaching methods preferred by grade 9 students in Finland. International Journal of Science and Mathematics Education, 8(4), 611-632. doi:10.1007/s10763-009-9177-8

Kafle, N. P. (2011). Hermeneutic phenomenological research method simplified. Bodhi: An Interdisciplinary Journal, 5, 181-200.

Karacam, S. (2015). Beyond Inquiry Based Science Program: It's Relevance in Changing Students' Stereotypical Images about Scientist. Eurasia Journal of Mathematics, Science \& Technology Education, 12(8), 1971-1995. doi:10.12973/Eurasia.2016.1286a

Konnevesi Research Station (n.d.). Retrieved June 14, 2018, from www.jyu.fi/science/en/ konnevesi-research-station.

Laverty, S. M. (2003). Hermeneutic phenomenology and phenomenology: A comparison of historical and methodological considerations. International Journal of Qualitative Methods, 2(3), 21-35. doi:10.1177/160940690300200303

Leblebicioglu, G., Metin, D., Yardimci, E., \& Cetin, P. S. (2011). The Effect of Informal and Formal Interaction Between Scientist and Children at a Science Camp on Their Images of Scientists. Science Education International, 22(3), 158-174.

Leblebicioglu, G., Abik, N. M., Capkinoglu, E., Metin, D., Eroglu Dogan, E., Cetin, P. S., \& Schwartz, R. (2017). Science camps for introducing nature of scientific inquiry through student inquiries in nature: Two applications with retention study. Research in Science Education, pp. 1-25. doi:10.1007/s11165-017-9652-0.

Lederman, H. G., Antink, A., \& Bartos, S. (2014). Nature of science, scientific inquiry, and socio-scientific issues arising from genetics: A pathway to developing a scientifically liberate citizenry. Science \& Education, 23(2), 285-302. doi:10.1007/s11191-012-9503-3

Ma, J., \& Nickerson, J. V. (2006). Hands-on, simulated, and remote laboratories: A comparative literature review. Journal ACM Computing Surveys (CSUR), 38(3), Article No. 7. doi:10.1145/1132960.1132961

Metin, D., \& Leblebicioglu, G. (2011). How Did a Science Camp Affect Children's Conceptions of Science? Asia-Pacific Forum on Science Learning and Teaching, 12(1), Article 2, 1-30.

Mitchell, C., Theron, L., Stuart, J., Smith, A., \& Campbell, Z. (2011). Drawings as Research Method. In: L. Theron, C. Mitchell, A. Smith, \& J. Stuart (Eds.) Drawings as Visual Methodology (pp. 19-36). Rotterdam: Sense Publishers. doi:10.1007/978-94-6091-596-3_2

Moreno, N. P., Tharp, B. Z., Vogt, G., Newell, A. D., \& Burnett, C. A. (2016). Preparing students for middle school through after-school STEM activities. Journal of Science Education and Technology, 25(6), 889-897. doi:10.1007/s10956-016-9643-3

Nuora, P. (2016). Monitapaustutkimus LUMA-toimintaan liittyvissä oppimisympäristöissä tapahtuvista kemian oppimiskokemuksista. (In English: A multiple case study which examines chemistry learning experiences in learning environments related to STEM activity). Jyväskylä, Finland: University of Jyväskylä. Research report / Department of Chemistry, University of Jyväskylä, 197.

Näsäkkälä, E., Flinkman, M., \& Aksela, M. (2001). Luonnontieteellisen tutkimuksen tekeminen koulussa. (In English: Doing scientific research at school). Helsinki: Opetushallitus. 
Ornstein, A. (2006). The frequency of hands-on experimentation and student attitudes toward science: A statistically significant relation (2005-51-Ornstein). Journal of Science Education and Tehnology, 15(3), 285-297. doi:10.1007/s10956-006-9015-5

Osborne, J., \& Dillon, J. (2008). Science education in Europe: A report from the Nuffield Foundation. London: The Nuffield Foundation.

Patton, M. Q. (2015). Qualitative research \& evaluation methods. $4^{\text {th }}$ ed. United Kingdom: SAGE Publications.

Punch, S. (2002). Research with children: The same of different from research with adults? Childhood, 9(3), 321-341. doi:10.1177/0907568202009003005

Rennie, L. J. (2007). Learning science outside of school. In: S. K. Abell, \& N. G. Lederman (Eds.) Handbook of research on science education, 1, (pp. 120-144). London: Lawrence Erlbaum Ass.

Schwartz, R. S., Lederman, N. G., \& Crawford, B. A. (2004). Developing view of nature of science in an authentic context: an explicit approach to bridging the gap between nature of science and scientific inquiry. Science Education, 88(4), 610-645. doi:10.1002/sce.10128

Tang, X., Coffey, J. E., Elby, A., \& Levin, D. M. (2009). The scientific method and scientific inquiry: Tensions in teaching and learning. Science Education, 94(1), 29-47. doi:10.1002/sce.20366

Tuomi, J., \& Sarajärvi, A. (2013). Laadullinen tutkimus ja sisällönanalyysi. (In English: Quality research and content analysis). Helsinki: Tammi.

Uitto, A., Juuti, K., Lavonen, J., \& Meisalo, V. (2006). Students' interest in biology and their out-ofschool experiences, Journal of Biological Education, 4O(3), 124-129. doi:10.1080/00219266.20 06.9656029

Williams, D. C., Ma, Y., Prejean, L., Ford, M. J., \& Lai. G. (2007). Acquisition of physics content knowledge and scientific inquiry skills in a robotics summer camp. Journal of Research on Tehnology in Education, 4O(2), 201-216. doi:10.1080/15391523.2007.10782505

Wilson, H. S., \& Hutchinson, S. A. (1991). Triangulation of qualitative methods: Heideggerian hermeneutics and grounded theory. Qualitative Health Research, 1(2), 263-276. doi:10.1177/104973239100100206

Young, M. R. (2002). Experiential learning = hands-on + minds-on, Marketing Education Review, 12:1, 43-51. doi:10.1080/10528008.2002.11488770

Zion, M., \& Mendelovici, R. (2012). Moving from structured to open inquiry: Challenges and limits. Science Education International, 23(4), 383-399. 